\title{
Predicting Thermal Stability of Organic Solar Cells Through an Easy and Fast Capacitance Measurement
}

\author{
Marta Tessarolo, ${ }^{\mathrm{a}, \mathrm{b}}$ Antonio Guerrero, ${ }^{\mathrm{b} *}$, Desta Gedefaw, ${ }^{\mathrm{c}}$ Margherita Bolognesi, ${ }^{\mathrm{d}}$ Mario \\ Prosa, ${ }^{a}$ Xiaofeng Xu, ${ }^{c}$ Mahdi Mansour, ${ }^{b}$ Ergang Wang, ${ }^{c}$ Mirko Seri, ${ }^{\text {e* }}$ Mats R. Andersson, ${ }^{c-f}$ \\ Michele Muccini, ${ }^{a}$ Germà Garcia-Belmonte, ${ }^{b^{*}}$ \\ ${ }^{a}$ Consiglio Nazionale delle Ricerche (CNR), Istituto per lo Studio dei Materiali Nanostrutturati (ISMN), Via P. Gobetti, 101, \\ 40129, Bologna, Italy. \\ ${ }^{\mathrm{b}}$ Photovoltaic and Optoelectronic Devices Group, Departament de Física, Universitat Jaume I, ES-12071 Castelló, Spain. \\ c Department of Chemistry and Chemical Engineering, Polymer Technology, Chalmers University of Technology, Goteborg, \\ SE-412 96, Sweden. \\ d Laboratory MIST E-R, Via P. Gobetti, 101, 40129, Bologna, Italy. \\ ${ }^{\mathrm{e}}$ Consiglio Nazionale delle Ricerche (CNR), Istituto per la Sintesi Organica e la Fotoreattività (ISOF), Via P. Gobetti, 101, \\ 40129, Bologna, Italy. \\ ${ }_{\mathrm{f}}^{\mathrm{f}}$ Ian Wark Research Institute, University of South Australia, Mawson Lakes, South Australia 5095, Australia.
}

Corresponding authors’ email: aguerrer@uji.es (A. Guerrero), garciag@uji.es (G. Garcia Belmonte), mirko.seri@isof.cnr.it (M. Seri)

\begin{abstract}
Degradation of Organic Photovoltaic (OPV) devices is currently a topic under intense research as it is one of the main limitations towards the commercialization of this technology. Morphological changes at both active layer and interfaces with the outer contacts are believed to determine main key issues to be overcome. In-line techniques are essential to rule out any effect arising during sample fabrication. Unfortunately, the number of physical techniques able to provide morphological information on complete and operational devices is certainly limited. In this work, we study the thermal degradation of bulk heterojunction $(\mathrm{BHJ})$ solar cells composed by different donor polymers with techniques developed to provide in-situ information on operational devices. Capacitance measurement as a function of temperature monitors the electrical integrity of the active layer and provides the threshold temperature $\left(T_{M A X}\right)$ at which the whole device becomes thermally unstable. We found a direct correlation between the threshold temperature $T_{M A X}$, obtained by capacitance-temperature measurements on complete OPV devices, and the power conversion efficiency decay measured at $85^{\circ} \mathrm{C}$. Devices show to be thermal stable when the temperature of the thermal stress is below the $T_{M A X}$, while above the $T_{M A X}$ evident changes in the active
\end{abstract}


layer or at the active layer/electrode interface are also detected by confocal fluorescence microscopy. The capacitance method gives precious guidelines to predict the thermal stability of BHJ solar cells using accelerated and easy tests.

\section{Keywords}

Thermal stability, capacitance, bulk heterojunction, confocal microscopy, thermal degradation, morphological changes

Published in Solar Energy Materials \& Solar Cells 141 (2015) 240-247 


\section{Introduction}

Organic photovoltaic (OPV) devices have to fulfill two fundamental requirements to be competitive in the field of renewable energy sources: $i$ ) power conversion efficiency (PCE) over 10\% [1,2] and ii) lifetime of at least 7-10 years [3]. Recently, laboratory-scale bulk heterojunction (BHJ) solar cells have reached the milestone of $11 \%$ [4], through a synergic development of increasingly high performing photoactive materials [5-9], understanding of the morphological film nanostructure $[10,11]$ and device structure optimization [1218]. However, the achievement of high performance has little technological impact if the resulting device lifetime is unsuitable for the technological requirements. For outdoors applications thermal degradation is a key factor that needs to be controlled, as solar panels usually reach temperatures as high as $65-85^{\circ} \mathrm{C}$ [19]. Recent studies on several highly efficient OPV devices showed severe efficiency losses even after a short operation time [20]. For this reason, a number of research groups are focused on boosting the lifetime of OPV devices through a deeper study of the degradation mechanisms, attempting to identify, prevent and/or limit them.

Krebs et al. [21] have comprehensively reviewed the most common degradation mechanisms taking place in organic photovoltaic. Different physical agents such as humidity, oxygen, UV light and temperature exposure need to be taken into account when studying the degradation of operating OPV devices. Diffusion of water [22] and molecular oxygen [23-25] into the device promotes chemical degradation of interfaces [23] and active material [26]. These effects can be discarded if a device is properly encapsulated. However, degradation pathways due to light soaking and high temperature cannot be eliminated, and, in general, they induce morphology evolution of the active layer [27], interlayer and electrode diffusion [28], and electrode interaction with the organic materials [29]. The behavior of BHJ OPVs with thermal degradation is generally correlated to morphological changes occurring in the active layer that can affect: $i)$ charge separation process by formation of fullerene aggregates in polymer:fullerene blends, which leads to a PCE loss due to the reduction of the donor:acceptor (D:A) interfacial area [30-32], ii) charge extraction by a migration of a skinlayer of either polymer [33] or fullerene [34] adhering to the top contact, generating barriers or selective transport regions as a function of the device architecture; iii) transport properties by modification of the polymer packing in the blend [35, 36], iv) recombination by an increase of the number of defect states at the bulk of the active layer [37], v) optical properties by generation of a charge transfer complex between donor and acceptor molecules which also acts as an exciton quencher [38]. Several works [31, 32] demonstrated that morphological reorganization processes occur only if the solar cell is subjected to temperatures near or above the glass transition temperature $(T g)$ of the donor polymer. At this temperature devitrification of the blend allows the polymer and the fullerene molecules to rearrange/diffuse in the bulk and at the interface with the electrodes. Typically the $T g$ of a polymer/blend is measured by Differential Scanning Calorimetry (DSC) [39] but other techniques like ellipsometry have also been employed [36]'[40]. Obtained $T g$ value is not always a well-defined parameter and in many systems a clear transition is not observed. Moreover, this value depends on several aspects such as the thermal history of the sample, the technique/method followed and the thermal rate used for the measurement [41]. For example, recent experiments [42, 43] and simulation [44] studies have demonstrated a pronounced thickness-dependent confinement effect on $T g$, together with a strong dependence on the solvent and on the substrate used [45]. These effects are totally disregarded if a technique like DSC is employed. On the other hand, ellipsometry can account for this thickness dependence 
but the presence of the buffer layers and of the electrodes is still not taken into account. In fact, the morphological rearrangement of the BHJ blend which occurs at temperatures above $T g$ may not be the same in presence or in absence of the top electrode, as demonstrated by several works with the so called "confinement effect" [46]. Taking into account all these considerations, it emerges that it is difficult to predict the thermal behavior of a BHJ solar cell through the bare analysis of the $T g$ of pristine materials and/or blend films (e.g. measured by DSC or ellipsometry). Indeed, to have a good description of the thermal stability of a solar cell it is crucial to study the proprieties of the complete device, taking into account the contribution of each layer and each interface on the degradation processes at the same time.

In this work, we study the thermal behavior of different BHJ solar cells using techniques enabling a direct investigation on working devices, such as: i) current density-voltage characterization to control the evolution of the photovoltaic parameters during the thermal degradation, ii) capacitance measurements as a function of temperature to monitor the electrical integrity of the active layer, and iii) fluorescence imaging by Confocal Microscopy to provide visual evidences. Five donor polymers, P(1)-FQ-BDT-4TR, P(2)-PTB7, P(3)-P3HT, P(4)-PTT-MIM, P(5)-PBnDT-FTAZ (Figure 1), which represent a broad range of different types of conjugated polymers, were selected and specific properties of the corresponding BHJ devices were characterized and correlated with the thermal degradation. As a result, we found a direct correlation between the threshold temperature $T_{M A X}$, obtained by capacitance-temperature measurements on complete OPV devices, and the PCE decay profile measured at $85^{\circ} \mathrm{C}$. In summary, this methodology provides a threshold temperature at which the whole device becomes thermally unstable, thus giving precious guidelines to predict the thermal stability of BHJ solar cells using accelerated tests.

\section{Experimental Section}

For this study we used a standard device architecture: glass/ITO/PEDOT:PSS/Active Layer/ZnO/Ag.

The PEDOT:PSS (poly(3,4-ethylenedioxythiophene):poly(4-styrenesulfonate), Clevios P VP A1 4083, H.C Starck) was spun-cast on a pre-cleaned patterned ITO-coated glasses (Rs $~ 10 \Omega / \square$ ) to form a thin layer $(\sim 30 \mathrm{~nm})$ and subsequently annealed at $150{ }^{\circ} \mathrm{C}$ for $15 \mathrm{~min}$. Different active layers based on the donor polymers P(1)-FQ-BDT-4TR, P(2)-PTB7, P(3)-P3HT, P(4)-PTT-MIM, P(5)-PBnDT-FTAZ were prepared. As acceptor materials we used $\mathrm{PC}_{61} \mathrm{BM}\left([6,6]\right.$ - phenyl- $\mathrm{C}_{61}$-butyric acid methyl ester, Solenne $\left.\mathrm{BV}\right)$ or $\mathrm{PC}_{71} \mathrm{BM}$ ([6,6]- phenyl- $\mathrm{C}_{71}$-butyric acid methyl ester, Solenne BV). The active layers were prepared by spin coating inside the glove-box. The following devices were prepared using recipes reported in literature: $\mathrm{P}(1): \mathrm{PC}_{61} \mathrm{BM}(1: 1 \mathrm{w} / \mathrm{w})[47], \mathrm{P}(2): \mathrm{PC}_{71} \mathrm{BM}(1: 1,5 \mathrm{w} / \mathrm{w})^{12}, \mathrm{P}(3): \mathrm{PC}_{61} \mathrm{BM}(1: 0,8 \mathrm{w} / \mathrm{w})[48]$ and $\mathrm{P}(5): \mathrm{PC}_{61} \mathrm{BM}$ $(1: 2 \mathrm{w} / \mathrm{w})[49]$. On the other hand, $\mathrm{P}(4): \mathrm{PC}_{61} \mathrm{BM}(1: 1,5 \mathrm{w} / \mathrm{w})$ was deposited from a solution of 1,2dichlorobenzene and 1,8-Diiodooctane $(98: 2 \mathrm{v} / \mathrm{v})$ with a total concentration of $30 \mathrm{mg} / \mathrm{ml}$ by spinning at 700 rpm for $120 \mathrm{~s}$. Details of the synthesis of $\mathrm{P}(4)$ are reported in the Supporting Information.

The $\mathrm{ZnO}$ (provided by Genes'Ink, Lab'Ink Jet $\mathrm{ZnO}$ ) was spun cast (inside the glove-box) on the top of the active layer to get a thickness of $50 \mathrm{~nm}$. To complete the device fabrication, Ag (100 nm) was next deposited in high vacuum $\left(\approx 1 \times 10^{-6}\right.$ Torr $)$ using a thermal evaporator directly connected to the glove-box. The currentvoltage $(I-V)$ characteristics of all OPV devices were recorded by a Keithley 236 source-measure unit under simulated AM1.5G illumination of $100 \mathrm{~mW} / \mathrm{cm}^{2}$ (Abet Technologies Sun 2000 Solar Simulator) inside the glove box. The active area of the devices is $6 \mathrm{~mm}^{2}$. The devices were illuminated through a calibrated mask 
to avoid the parasitic photocurrent arising from the areas outside the electrodes. The results shown in this work are an average on 6 devices.

The thermal degradation tests were carried out inside the glove-box, by keeping the devices onto a hotplate at $85^{\circ} \mathrm{C}$ and measuring them at defined intervals of time, to register the trend of the OPV parameters. The total measurement time under light was shorter than 30 minutes to avoid the initial burn-in light induced degradation [20].

To determinate the capacitance-temperature dependence, encapsulated devices were measured in an oven in air. Samples were heated at ramp of $1^{\circ} \mathrm{C} / \mathrm{min}$ from $25^{\circ} \mathrm{C}$ to $140^{\circ} \mathrm{C}$ and the capacitance was measured every 10 second. Capacitance was measured using a Gamry Instruments Reference 3000 potentiostat/galvanostat/ZRA by applying a small voltage perturbation $(20 \mathrm{mV})$ to guarantee the linearity of the response. The chosen frequency was $10 \mathrm{kHz}$ for $\mathrm{P}(1), 100 \mathrm{kHz}$ for $\mathrm{P}(3), 1 \mathrm{kHz}$ for $\mathrm{P}(2), \mathrm{P}(4)$ and $\mathrm{P}(5)$ and the applied voltage was $-1 \mathrm{~V}$ for each device. These conditions enable monitoring the dielectric capacitance of the active layer. Results shown in this work are an average on 2 representative devices.

Laser scanning confocal fluorescence microscopy (LSCM) was carried out on both freshly prepared and aged devices to monitor the evolution of the active layer morphology with thermal degradation. We used a Nikon TE2000 optical microscope connected with a Nikon EZ-1 confocal scanning head. The laser excitation wavelength was $488 \mathrm{~nm}$. The encapsulated devices were illuminated through the glass/ITO side in the area under the metal electrode. The laser was focused inside the device at a depth corresponding to the active layer and the corresponding confocal photoluminescence signal was collected in reflection mode, through the same optical path of the excitation light. By scanning the samples over a defined area, a twodimensional map of the photoluminescence intensity is created.

\section{Results and Discussion}

The selection of polymers in this work (Figure 1) was such to include two of the most widely used donor polymers (P3HT and PTB7) and three other materials synthesized in-house with totally different structural units and different proportion of alkyl chains and branching points [50, 51]. Characterization of these polymers by DSC measurements was carried out in two independent research laboratories (examples are shown in Figure S1 in Supporting Information). Unfortunately, none of the materials provided a clear transition to assign the $\mathrm{Tg}$ in the range of temperature considered. This result could be due to the combination of chemical structure and relatively low molecular weight of the materials (reported in Supporting Information Table S1), indeed it has been reported that the $T g$ of P3HT with low molecular weight, is situated at temperatures as low as $12^{\circ} \mathrm{C}$ [52]. Despite the difficult of the DSC measurement interpretation on the pure polymer, it is necessary to consider that after blending with fullerene molecules $T g$ values might change dramatically [53] by effect of restructuring. Therefore, device thermal stability not only depends on the polymer properties but also on the rest of constituents as discussed in the Introduction. Accordingly, a standard method, as the determination of polymer $T g$, cannot be used as a simple guide to predict thermal stability. A range of alternative physical techniques were explored here as next described. 


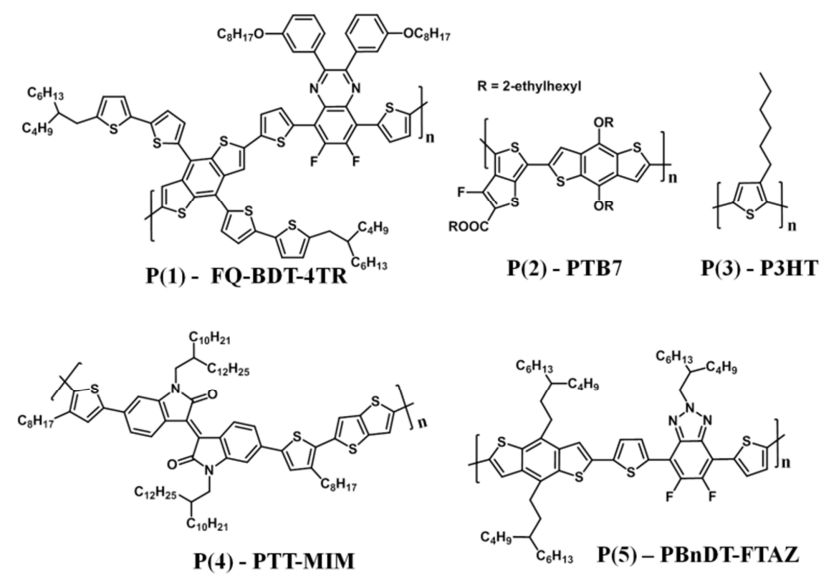

Figure 1. Chemical structure of the photoactive polymers

\subsection{Lifetime Study}

All solar cells were fabricated using the same device structure composed by ITO/PEDOT:PSS/Polymer:PCBM/ZnO/Ag. We selected the $\mathrm{ZnO} / \mathrm{Ag}$ cathode to prevent additional degradation processes, such as oxidation and diffusion, that could occur at the active layer/electrode interface when using other common materials such as $\mathrm{Ca} / \mathrm{Al}$ [54] or LiF/Al [55]. It should be noted that the initial PCE could be slightly enhanced by further optimizing both the processing conditions and the device stack. However the achievement of "hero" efficiency is out of the aim of this work. Interestingly, a different and/or suboptimal self-organization of the same BHJ active blend affords different PCEs and likely different thermal stabilities of the resulting devices. To this end, our approach can be used for each specific device, independently from the initial PCE, giving an univocal response on its typical thermal resistance. An example of different responses of two $\mathrm{P}(1)$ based devices, having different initial PCEs, is reported in the SI (Table S2 and Figure S3-S4).

The thermal degradation test was performed at $85^{\circ} \mathrm{C}$ as a standard temperature [19] and inside the glove-box to prevent interactions of devices with oxygen and/or moisture. The test runs for 20 hours and the solar cells were illuminated to monitor the OPV performance for a total period shorter than 30 minutes, allowing to neglect the initial burn-in light induced degradation [20]. The following degradation effects on the photovoltaic parameters are expected: i) a reduction of the short circuit current density $\left(J_{\mathrm{sc}}\right)$ due to morphological changes of the BHJ blend $[27,35,36]$ that can affect the charge mobility and the generation of a charge transfer complex; ${ }^{38}$ ii) a variation of the open circuit voltage $\left(V_{\mathrm{oc}}\right)$ as a consequence of a different D:A phase segregation [56] and increase of defect states which controls the recombination [37]; iii) those phenomena can affect also the fill factor $(\mathrm{FF})$, by a limitation of the charge transport and increase in the series resistance [38]. 

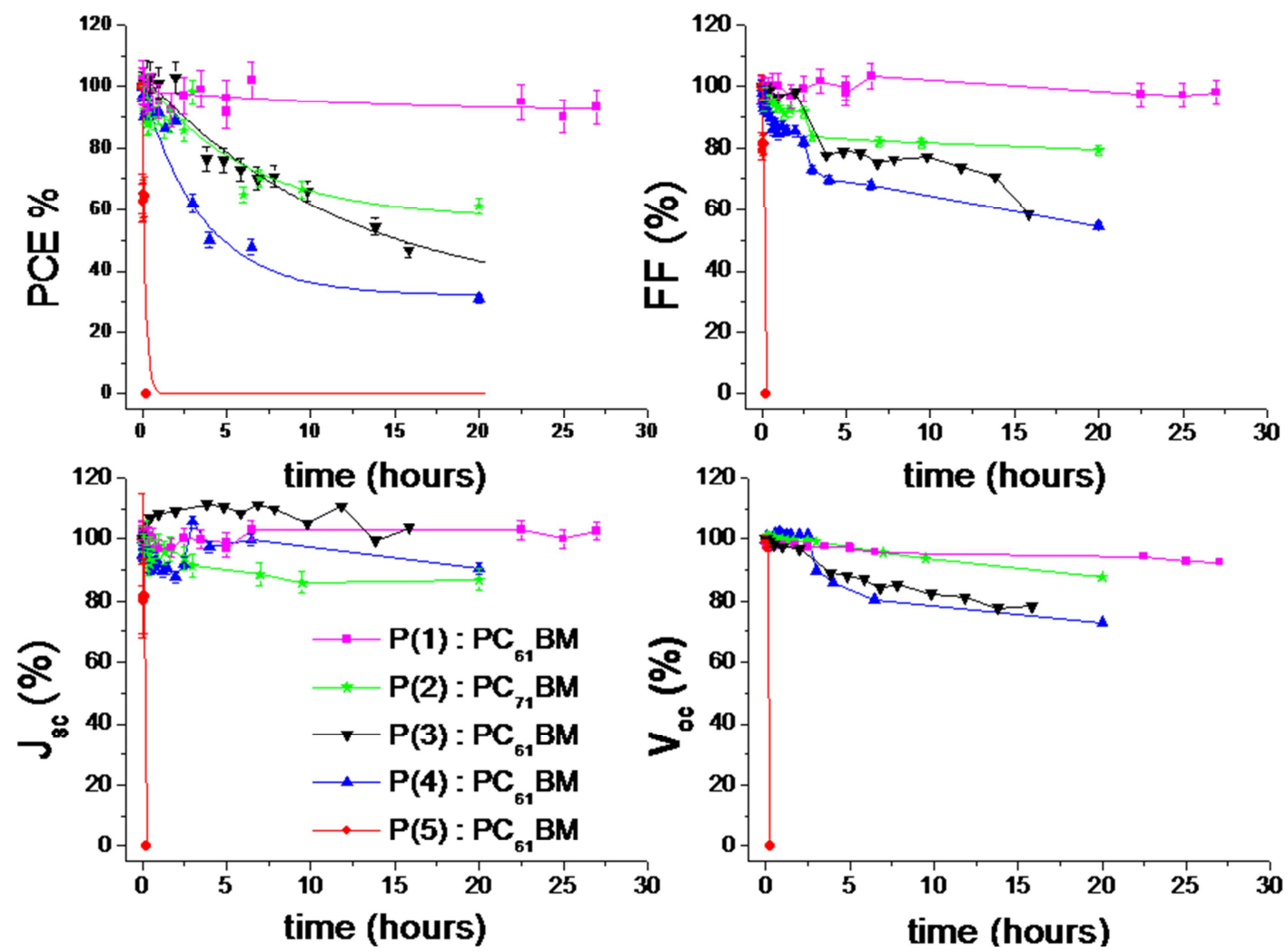

Figure 2. Evolution with time of the normalized photovoltaic parameters for devices thermally treated at $85^{\circ} \mathrm{C}$ in the glovebox.

Table 1. OPV Performance of the different BHJ solar cells, before and after the thermal test. (a) Time constant $\tau$ and offset $\mathrm{PCE}_{f}$ calculated from PCE decay during the thermal test at $85^{\circ} \mathrm{C}$ in glovebox, (b) value of $T_{M A X}$ obtained from the capacitance versus temperature measurement.

\begin{tabular}{ccccccccc}
$\begin{array}{c}\text { Donor } \\
\text { material }\end{array}$ & $\begin{array}{c}\text { Time } \\
(\mathbf{h})\end{array}$ & $\begin{array}{c}\boldsymbol{J}_{\mathbf{s c}} \\
\left(\mathbf{m A} / \mathbf{c m}^{2}\right)\end{array}$ & $\boldsymbol{V}_{\mathbf{o c}}(\mathbf{V})$ & $\mathbf{F F}$ & $\mathbf{P C E}$ & $\begin{array}{c}\boldsymbol{\tau}^{(\mathbf{a})} \\
(\mathbf{h})\end{array}$ & $\mathbf{P C E}_{f}{ }^{(\mathbf{a})}$ & $\begin{array}{c}\boldsymbol{T}_{\boldsymbol{M A X}}{ }^{(\mathbf{b})} \\
\left({ }^{\circ} \mathbf{C}\right)\end{array}$ \\
\hline \multirow{2}{*}{$\mathrm{P}(1)$} & 0 & 7,3 & 0,89 & $47 \%$ & $3,1 \%$ & & & \\
& 20 & 7,5 & 0,85 & $46 \%$ & $2,9 \%$ & 15 & $92 \%$ & 702 \\
\hline \multirow{2}{*}{$\mathrm{P}(2)$} & 0 & 7,5 & 0,82 & $46 \%$ & $2,9 \%$ & & & 77 \\
\hline $\mathrm{P}(3)$ & 20 & 13,5 & 0,71 & $50 \%$ & $5,4 \%$ & 6 & $57 \%$ & 74
\end{tabular}




\begin{tabular}{ccccccccc} 
& 20 & 5,2 & 0,46 & $34 \%$ & $0,8 \%$ & & \\
\hline $\mathrm{P}(4)$ & 0 & 8,8 & 0,76 & $50 \%$ & $3,4 \%$ & 3,5 & $32 \%$ \\
& 20 & 7,8 & 0,51 & $37 \%$ & $1,5 \%$ & 58 & \\
\hline \multirow{2}{*}{$\mathrm{P}(5)$} & 0 & 8,3 & 0,78 & $44 \%$ & $2,8 \%$ & 0,2 & 53 \\
& 0.16 & 6,8 & 0,75 & $36 \%$ & $1,8 \%$ & &
\end{tabular}

Table 1 summarizes the OPV response data, before and after thermal degradation, of the different polymer based BHJ solar cells. To better analyze the trend of the OPV performance of each device, normalized PCE, $V_{\mathrm{oc}}, J_{\mathrm{sc}}$ and FF, as function of time are reported in Fig 2. Fitting of the PCE data (Fig 2a) was carried out using an exponential decay: $\mathrm{PCE}=\mathrm{PCE}_{f}+\left(1-\mathrm{PCE}_{f}\right) \exp (-t / \tau)$, where $t$ represents the experiment time, $\mathrm{PCE}_{f}$ is the final value attained by the efficiency and accounts for the percentage of the initial efficiency preserved after thermal degradation, while the time constant $\tau$ is the lifetime at which the efficiency value is decreased by a factor $e$, and allows to compare the kinetic of the PCE decay of each samples. The $\mathrm{PCE}_{f}$ and $\tau$ values are reported for each device in Table 1.

The most stable device is based on the polymer $\mathrm{P}(1)$ as shown in Figure 2. The drop in normalized PCE is only of $7 \%$ after 20 hours at $85^{\circ} \mathrm{C}$. For this polymer all the photovoltaic parameters (Figure $2 \mathrm{~b}-\mathrm{d}$ ) remain constant during the experiment time, negligible thermally-induced morphological changes are expected to occur. This result is most probably due to the chemical structure of the polymer with a high proportion of 2D $\pi$-conjugated aromatic rings in comparison to the free rotation alkyl chains (Figure 1) [47]. This configuration allows strong intra- and inter-molecular interactions of the polymer chains which might also hinder the diffusion of the fullerene molecules, leading to thermodynamically stable thin-film morphology as it will be shown below. In the other extreme, devices fabricated with $\mathrm{P}(5)$ degraded very fast: after 1 minute of thermal stress PCE drops to $65 \%$ of the initial value by the fast initial decay in $J_{\mathrm{sc}}$ and FF, leading to a very low efficiency after only 15 minutes (Figure 2a). For P(5) important morphological reorganization of the polymer occurs due to the presence of up to three branched alkyl chains in the monomer unit, dramatically reducing the hypothetical $T g$. Devices fabricated with the donor polymers $\mathrm{P}(2)-\mathrm{P}(4)$ show an intermediate behavior between these two border cases.

The $\mathrm{P}(2)$ based device shows a $\tau$ of 6 hours and a $\mathrm{PCE}_{f}$ of $57 \%$ (Table 1), with a PCE drop from an initial value of $5,4 \%$ to a value of $3,3 \%$ after $20 \mathrm{~h}$ (Table 1 ). The main factor influencing the degradation trend is FF (Figure $2 b$ ), which drastically decreases due to an increased series resistance in the device, which could be ascribed to a partial segregation between the donor and the acceptor phases within the active layer [35]. This thermally induced reorganization also leads the polymeric chains to rearrange into a morphology with lower charge mobility, as confirmed by the simultaneous decrease of $J_{\mathrm{sc}}$ from $15,5 \mathrm{~mA} / \mathrm{cm}^{2}$ to $13,5 \mathrm{~mA} / \mathrm{cm}^{2}$ (Figure 2c). Finally, the $\mathrm{P}(3)$ and $\mathrm{P}(4)$ based solar cells show similar $\mathrm{PCE}_{f}(29 \%$ and $32 \%$ respectively) but different $\tau$ (12 hours and 3,5 hours, respectively), as shown in Table 1 . In the case of $\mathrm{P}(3)$, the device shows a constant efficiency during the first 3,5 hours of thermal test, while after that time the PCE starts to decrease. As suggested by Bertho et al. in a previous report [32], in the P3HT:PCBM active layer two morphological reorganization processes, with different kinetics, take place. Analogously, in the case of the P(4) based solar cell two degradation mechanisms are taking place: one which affects FF (Figure 2b) due to an increase in the series resistance in the device, and a second, with a slower kinetic, mostly affecting $V_{\text {oc }}$ (Figure 2d). 


\subsection{Capacitance vs temperature measurements}

To further analyze the thermal response of each polymer based device we have developed a new method based on the variation of the capacitance as a function of temperature $(C-T)$. This method is based on the model proposed by Lungenschmied et al. where the geometrical capacitance $(C g)$ is used to monitor morphological changes in operating devices [57]. $C g$ can be expressed by the equation $C g=\varepsilon \varepsilon_{0} A / L$ where $A$ is the area of the device, $L$ is the thickness of the active layer, $\varepsilon_{0}$ the dielectric constant of vacuum and $\varepsilon$ the static permittivity of the active layer. When the temperature is increased two phenomena can influence $C g$ due to significant morphological modification of the active layer: i) variation of the active layer thickness $(L)$, and ii) change in the dielectric properties of the blend $(\varepsilon)$ [58]. To define the conditions at which the $C g$ should be monitored, we measured the capacitance-voltage characteristics in the dark for each system, from $-1 \mathrm{~V}$ to $1,5 \mathrm{~V}$ at different frequencies. At a certain frequency, typical of each device, the curve has a planar trend in reverse bias, this means that full depletion is achieved in such a way that depletion region covers the whole thickness of the active layer [48]. In this range, the capacitance value corresponds to a geometrical capacitance. (See supporting information Figure S2 for details). Once selected the correct frequency and applied voltage, devices were introduced in an oven with a heating ramp of $1^{\circ} \mathrm{C} / \mathrm{min}$ and capacitance was monitored every 10 seconds. The variation of capacitance with respect to temperature for all $\mathrm{P}(1)-\mathrm{P}(5)$ based devices is reported in Figure 3. All the curves have been smoothed and normalized at their maximum to simplify their comparison. A brown dash line at $85^{\circ} \mathrm{C}$ indicates the temperature of the standard thermal degradation test described in the previous section. For all devices, except the specific case of $\mathrm{P}(5)$, the $C-T$ curve shows an initial rise after which capacitance reaches a maximum value, in correspondence to a temperature defined as $T_{M A X}$ (Table1), and then starts to decrease. The initial rise is in agreement with previous work on P3HT based devices[40] $(\mathrm{P}(3))$ where the increase in $C g$ was related to a reduction of the film thickness as a consequence of an increased phase-separation of the BHJ components and possibly to residual solvent loss, resulting in an overall reduction of the free volume of the BHJ films.[36] Moreover Pearson at al. [59] observed that the PEDOT:PSS layer has a thickness contraction in the low temperature range up to $70^{\circ} \mathrm{C}$, which can partially contribute to the initial rise of $\mathrm{Cg}$.

A further increase in the temperature above the $T_{M A X}$ gives rise to a capacitance decrease. This fact could be attributed to additional physical or chemical processes occurring in the active layer and/or at the active layer/electrode interface which could modify the dielectric permittivity of the layer and/or the thickness of the active layer. To support these hypotheses, a rough theoretical calculation of the expansion coefficient of $\mathrm{P}(1)$ based device are reported in the SI (Table S3).

Despite the degradation process involved the presence of this maximum indicates that significant morphological rearrangements occur in the active blend in relation with the onset of the thermal stability.

The $T_{M A X}$ values extracted from the $C-T$ measurements correlates well with the thermal degradation behavior of the devices observed during the performance thermal tests. Indeed, by plotting the $\mathrm{PCE}_{f}$ and $\tau$ values, calculated from the PCE decays during the thermal stress at $85^{\circ} \mathrm{C}$, versus the corresponding $T_{\text {MAX }}$ obtained from the $C-T$ measurements (Figure $4 \mathrm{a}$ and $4 \mathrm{~b}$, respectively) for all devices, a clear and direct correlation is found. These findings suggest that the $T_{M A X}$ is a good indicator of the thermal stability of a device and it generally represents the limit operating temperature above which the device becomes thermally unstable. 


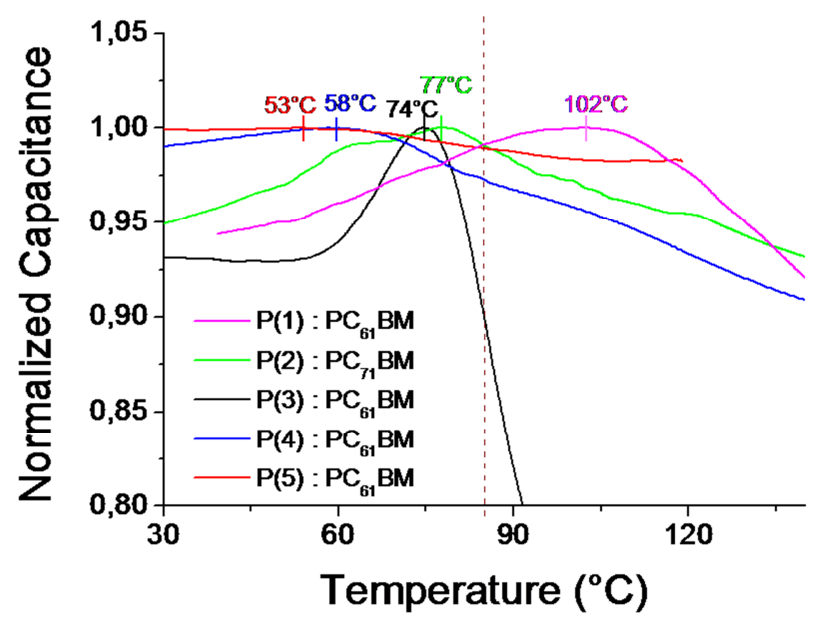

Figure 3. Normalized Capacitance of complete devices thermally treated with a heating ramp of $1^{\circ} \mathrm{C} / \mathrm{min}$. The brown dash line indicates the temperature of the thermal life test $\left(85 \mathrm{C}^{\circ}\right)$. The maximum of the Capacitance-Temperature $\left(T_{M A X}\right)$ is indicated in the graph for each system.

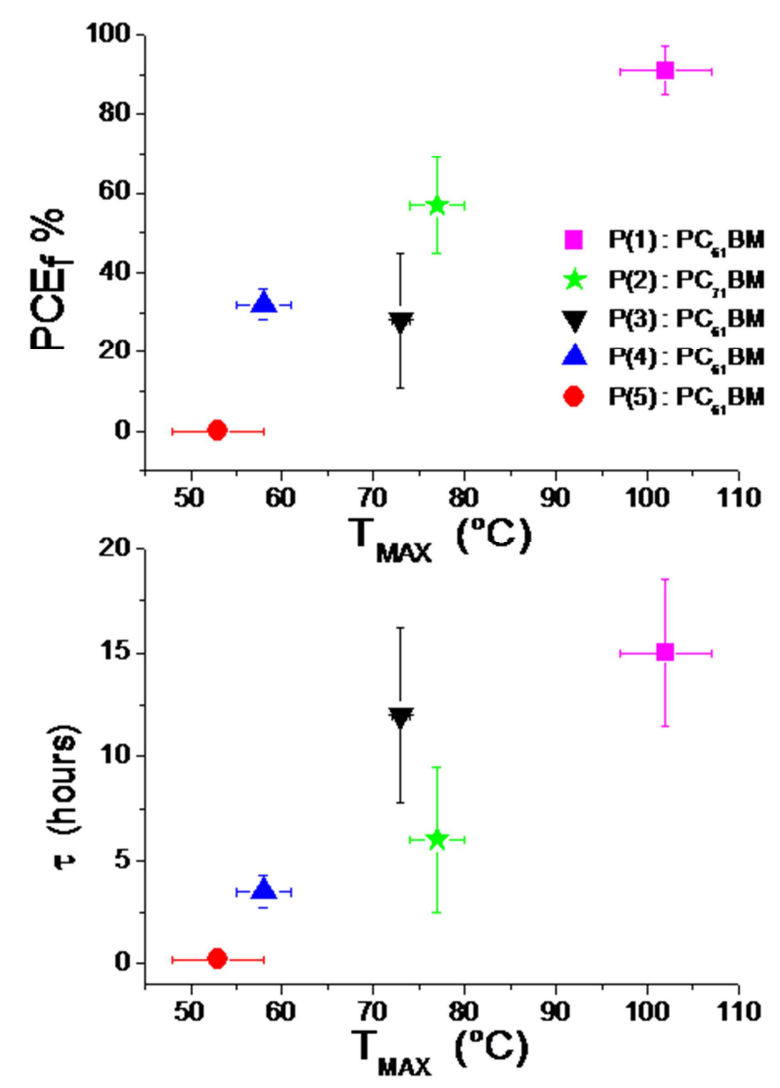


Figure 4. Correlation between $T_{M A X}$ and parameters extracted from life test at $85^{\circ} \mathrm{C}$ : a) Proportion of initial efficiency preservation $\left(\mathrm{PCE}_{f}\right)$ after thermal degradation and $\mathrm{b}$ ) time constant $\tau$ calculated from the PCE decay.

\subsection{Morphology information}

In order to further support that morphological changes are taking place with thermal degradation, we need a non-destructive technique that provides morphological information in freshly prepared and aged devices. Laser scanning confocal fluorescence microscopy (LSCM) is a non-invasive technique which allows observing directly the BHJ active layer morphology inside working devices (more details on the measurement are reported in the experimental section). The devices were scanned with a laser at $488 \mathrm{~nm}$ and the luminescence signal in the wavelength range 560-700 nm was acquired. At $488 \mathrm{~nm}$ light is absorbed only by the donor polymer and the observed variable is its unquenched residual luminescence from the charge generation process and from other minor energy deactivation pathways. The 2D maps acquired with LSCM represent therefore a projection of the BHJ active layer morphology, where the contrast is determined, within the instrumental resolution, by the different physical and chemical nature of the photoluminescent species in the bulk: domains enriched of donor $(\mathrm{D}$, polymer) would result brighter, while domains enriched of acceptor (A, fullerene) and/or finely intermixed D:A phases would result darker.[60] Confocal fluorescence images of two representative devices based on $\mathrm{P}(1)$ and $\mathrm{P}(3)$ were recorded first on freshly encapsulated devices, then on the same devices after thermal ageing at $85^{\circ} \mathrm{C}$ for $20 \mathrm{~h}$ and for $36 \mathrm{~h}$ (Figure 5). These two polymers $\mathrm{P}(1)$ and $\mathrm{P}(3)$ were selected as they showed a $T_{M A X}$ above and below, respectively, the temperature used during the thermal test $\left(85^{\circ} \mathrm{C}\right)$.

The LSCM images registered for the device fabricated with $\mathrm{P}(1)\left(T_{M A X}=102^{\circ} \mathrm{C}\right)$ reveal a featureless and homogeneous nanomorphology of the active layer (at the instrumental spatial resolution), which remains stable even after 36 hours of thermal stress at $85^{\circ} \mathrm{C}$ (Figure 5a-c). This is in perfect agreement with the nearly unaltered OPV performance of the device reported in Table 1. On the other hand, LSCM images registered for the device fabricated with $\mathrm{P}(3)\left(T_{M A X}\right.$ of $\left.74^{\circ} \mathrm{C}\right)$, which shows a significant decay of the photovoltaic parameters with thermal degradation at $85{ }^{\circ} \mathrm{C}$ (Table 1), are reported in Figures 5d-f. For this device an evident change in the morphology of the BHJ blend is observed after the thermal treatment. Indeed, at time $0 \mathrm{~h}$ (Figure 5a) the morphology is characterized by finely structured intermix of polymerrich domains (lighter spots) and fullerene-rich domains (darker spots). After 20 hours (and even more after 36 hours, Figure 4e and f, respectively) of thermal ageing, a clear reorganization of the blend is observed: the fine structuring of the polymer-rich and fullerene-rich domains disappears concomitantly to the growth of dark spots, which are attributed to fullerene micro-sized aggregates. This is in agreement with the decay of the photovoltaic parameters registered for the $\mathrm{P}(3)$ based device during the thermal degradation test at $85^{\circ} \mathrm{C}$ (Table 1). 

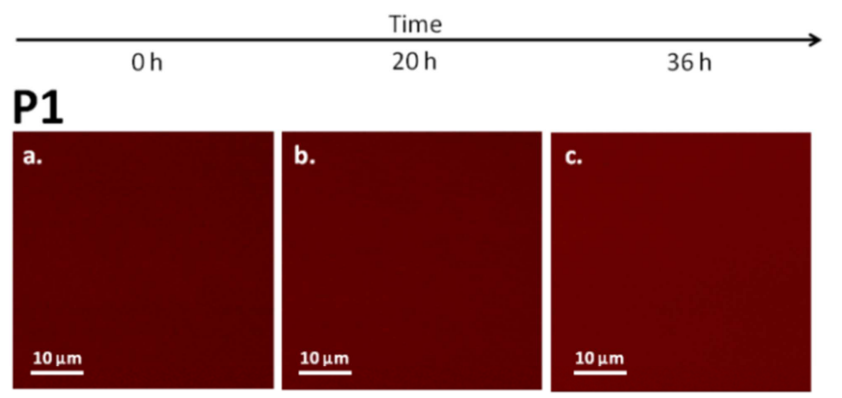

\section{P3}
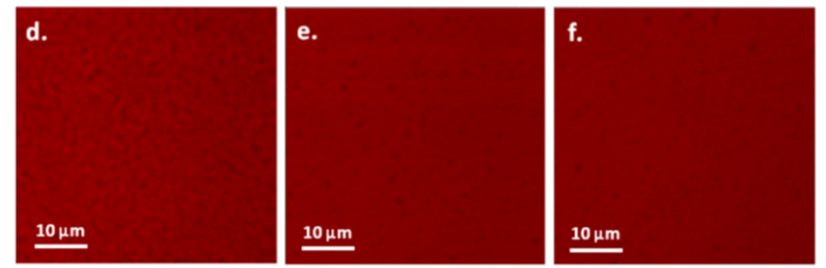

Figure 5. Confocal fluorescence images of devices thermally treated at $85{ }^{\circ} \mathrm{C}$ for different times: $\mathrm{P}(1)$ based device after 0 hours (a), 20 hours (b) and 36 hours (c) of thermal stress at $85^{\circ} \mathrm{C}$; P(3) based device after 0 hours (d), 20 hours (e) and 36 hours (f) of thermal stress at $85^{\circ} \mathrm{C}$. Laser excitation at $488 \mathrm{~nm}$. Images dimension: 50 x $50 \mu \mathrm{m}$.

For data completeness, a device fabricated with $\mathrm{P}(1)$ was thermally treated at $120^{\circ} \mathrm{C}$, which is a temperature slightly above $T_{M A X}$. In this case, evident morphological changes of the active layer or at the active layer/electrode interface are observed in the corresponding LSCM map (see Figure S5 in Supporting Information). The lifetime test at $120^{\circ} \mathrm{C}$ on the $\mathrm{P}(1)$-based device (Table S4 Figure S6) indeed revealed a drastic decrease of the photovoltaic performance at this temperature, with a decay time constant $(\tau)$ of 0.4 hours and an offset $\mathrm{PCE}_{f}$ of $71 \%$.

In summary, whilst a stable nanomorphology is observed for the $\mathrm{P}(1)$-based device treated at a temperature below its $T_{M A X}$, evident changes in the nanomorphology of the active layer or at the active layer/electrode interface are observed when the $\mathrm{P}(1)$ and $\mathrm{P}(3)$ based devices are aged at temperatures above their respective $T_{M A X}$

\section{Conclusions}

In this work we discuss the thermal degradation of organic photovoltaics due to the morphology evolution of the organic layer in complete devices. For this purpose we carried out lifetime tests at $85^{\circ} \mathrm{C}$ on a set of five different donor polymers. Degradation data are correlated with other two physical techniques which allow characterization on working devices to account for contact confinement effects. First, capacitancetemperature measurements provide electrical information on the active layer. At a characteristic temperature $\left(T_{M A X}\right)$ there is a change in capacitance response which is clearly correlated with the lifetime at a given temperature. As many conjugated polymers do not have a univocal $T_{\mathrm{g}}$ that can be detected by DSC, this technique developed in this work can be a very useful tools and have obvious advantages. On the other hand, laser confocal scanning microscopy provides information on the morphology evolution affecting the active layer and active layer/electrodes interfaces. Whilst stable morphologies are observed for the devices treated 
at a temperature below $T_{M A X}$, evident changes in the morphology of the active layer or at the active layer/electrode interface are observed at temperatures above the $T_{M A X}$. The capacitance method presented here constitutes a reliable, fast and easy testing tool to predict the thermal stability of BHJ solar cells.

\section{Acknowledgements}

This work was partially supported by FP7 European collaborative project SUNFLOWER (FP7-ICT-2011-7contract num. 287594), and Generalitat Valenciana (project ISIC/2012/008 Institute of Nanotechnologies for Clean Energies). We further acknowledge Laboratory MIST E-R within the Programma Operativo FESR 2007-2013 of Regione Emilia-Romagna (Attività I.1.1) for financial support and Vincenzo Ragona for the technical support. The Swedish Research Council was acknowledged for financial support, and Genes'Ink (Marseille, France) for providing $\mathrm{ZnO}$ (Lab'Ink Jet $\mathrm{ZnO}$ ).

\section{Notes and references}

Electronic Supplementary Information (ESI) available.

See DOI: $10.1039 / \mathrm{b} 000000 \mathrm{x} /$

[1] G. Dennler, M.C. Scharber, C.J. Brabec, Polymer-Fullerene Bulk-Heterojunction Solar Cells, Advanced Materials, 21 (2009) 1323-1338.

[2] H.J. Son, B. Carsten, I.H. Jung, L. Yu, Overcoming efficiency challenges in organic solar cells: rational development of conjugated polymers, Energy \& Environmental Science, 5 (2012) 8158-8158.

[3] H.-L. Yip, A.K.Y. Jen, Recent advances in solution-processed interfacial materials for efficient and stable polymer solar cells, Energy \& Environmental Science, 5 (2012) 5994-5994.

[4] C.-C. Chen, W.-H. Chang, K. Yoshimura, K. Ohya, J. You, J. Gao, Z. Hong, Y. Yang, An Efficient Triple-Junction Polymer Solar Cell Having a Power Conversion Efficiency Exceeding 11\%, Advanced Materials, 26 (2014) 5670-5677.

[5] L. Dou, W.-H. Chang, J. Gao, C.-C. Chen, J. You, Y. Yang, A selenium-substituted low-bandgap polymer with versatile photovoltaic applications, Advanced Materials, 25 (2013) 825-831. 
[6] Y.-J. Cheng, S.-H. Yang, C.-S. Hsu, Synthesis of conjugated polymers for organic solar cell applications, Chemical reviews, 109 (2009) 5868-5923.

[7] M. Seri, M. Bolognesi, Z. Chen, S. Lu, W. Koopman, A. Facchetti, M. Muccini, Fine Structural Tuning of Cyanated Dithieno[3,2- $b: 2^{\prime}, 3^{\prime}-\mathrm{d}$ ] silole-Oligothiophene Copolymers: Synthesis, Characterization, and Photovoltaic Response, Macromolecules, 46 (2013) 6419-6430.

[8] W. Zhuang, M. Bolognesi, M. Seri, P. Henriksson, D. Gedefaw, R. Kroon, M. Jarvid, A. Lundin, E. Wang, M. Muccini, M.R. Andersson, Influence of Incorporating Different Electron-Rich Thiophene-Based Units on the Photovoltaic Properties of Isoindigo-Based Conjugated Polymers: An Experimental and DFT Study, Macromolecules, (2013).

[9] M. Tessarolo, D. Gedefaw, M. Bolognesi, F. Liscio, P. Henriksson, W. Zhuang, S. Milita, M. Muccini, E. Wang, M. Seri, M.R. Andersson, Structural tuning of quinoxaline-benzodithiophene copolymers via alkyl side chain manipulation: synthesis, characterization and photovoltaic properties, Journal of Materials Chemistry A, 2 (2014) 11162-11170.

[10] C.R. McNeill, Morphology of all-polymer solar cells, Energy \& Environmental Science, 5 (2012) 5653-5653.

[11] M.T. Dang, L. Hirsch, G. Wantz, J.D. Wuest, Controlling the Morphology and Performance of Bulk Heterojunctions in Solar Cells . Lessons Learned from the Benchmark System, Chemical reviews, (2013).

[12] Z. He, C. Zhong, S. Su, M. Xu, H. Wu, Y. Cao, Enhanced power-conversion efficiency in polymer solar cells using an inverted device structure, Nature Photonics, 6 (2012) 591-595.

[13] S.-H. Liao, H.-J. Jhuo, Y.-S. Cheng, S.-A. Chen, Fullerene derivative-doped zinc oxide nanofilm as the cathode of inverted polymer solar cells with low-bandgap polymer (PTB7-Th) for high performance, Advanced Materials, 25 (2013) 4766-4771.

[14] J. Jo, J.-R. Pouliot, D. Wynands, S.D. Collins, J.Y. Kim, T.L. Nguyen, H.Y. Woo, Y. Sun, M. Leclerc, A.J. Heeger, Enhanced efficiency of single and tandem organic solar cells incorporating a diketopyrrolopyrrole-based low-bandgap polymer by utilizing combined $\mathrm{ZnO}$ /polyelectrolyte electron-transport layers, Advanced Materials, 25 (2013) 4783-4788.

[15] M. Bolognesi, M. Tessarolo, T. Posati, M. Nocchetti, V. Benfenati, M. Seri, G. Ruani, M. Muccini, Efficiency enhancement of P3HT:PCBM solar cells containing scattering Zn-Al hydrotalcite nanoparticles in the PEDOT:PSS layer, Organic Photonics and Photovoltaics, 1 (2013) 1-10. 
[16] N. Zhou, X. Guo, R.P. Ortiz, S. Li, S. Zhang, R.P.H. Chang, A. Facchetti, T.J. Marks, Bithiophene imide and benzodithiophene copolymers for efficient inverted polymer solar cells, Advanced Materials, 24 (2012) 2242-2248.

[17] L. Motiei, Y. Yao, J. Choudhury, H. Yan, T.J. Marks, M.E. van der Boom, A. Facchetti, Self-propagating molecular assemblies as interlayers for efficient inverted bulk-heterojunction solar cells, Journal of the American Chemical Society, 132 (2010) 12528-12530.

[18] M. Prosa, A. Sagnella, T. Posati, M. Tessarolo, M. Bolognesi, S. Cavallini, S. Toffanin, V. Benfenati, M. Seri, G. Ruani, M. Muccini, R. Zamboni, Integration of a silk fibroin based film as a luminescent down-shifting layer in ITO-free organic solar cells, RSC Adv., 4 (2014) 44815-44822.

[19] M.O. Reese, S.a. Gevorgyan, M. Jørgensen, E. Bundgaard, S.R. Kurtz, D.S. Ginley, D.C. Olson, M.T. Lloyd, P. Morvillo, E.a. Katz, A. Elschner, O. Haillant, T.R. Currier, V. Shrotriya, M. Hermenau, M. Riede, K. R. Kirov, G. Trimmel, T. Rath, O. Inganäs, F. Zhang, M. Andersson, K. Tvingstedt, M. Lira-Cantu, D. Laird, C. McGuiness, S. Gowrisanker, M. Pannone, M. Xiao, J. Hauch, R. Steim, D.M. DeLongchamp, R. Rösch, H. Hoppe, N. Espinosa, A. Urbina, G. Yaman-Uzunoglu, J.B. Bonekamp, A.J.J.M. van Breemen, C. Girotto, E. Voroshazi, F.C. Krebs, Consensus stability testing protocols for organic photovoltaic materials and devices, Solar Energy Materials and Solar Cells, 95 (2011) 1253-1267.

[20] C.H. Peters, I.T. Sachs-Quintana, W.R. Mateker, T. Heumueller, J. Rivnay, R. Noriega, Z.M. Beiley, E.T. Hoke, A. Salleo, M.D. McGehee, The mechanism of burn-in loss in a high efficiency polymer solar cell, Advanced Materials, 24 (2012) 663-668.

[21] M. Jørgensen, K. Norrman, F.C. Krebs, Stability/degradation of polymer solar cells, Solar Energy Materials and Solar Cells, 92 (2008) 686-714.

[22] K. Norrman, S.a. Gevorgyan, F.C. Krebs, Water-induced degradation of polymer solar cells studied by H2(18)O labeling, ACS Applied Materials \& Interfaces, 1 (2009) 102-112.

[23] M.O. Reese, A.J. Morfa, M.S. White, N. Kopidakis, S.E. Shaheen, G. Rumbles, D.S. Ginley, Pathways for the degradation of organic photovoltaic P3HT:PCBM based devices, Solar Energy Materials and Solar Cells, 92 (2008) 746-752.

[24] A. Guerrero, P.P. Boix, L.F. Marchesi, T. Ripolles-Sanchis, E.C. Pereira, G. Garcia-Belmonte, Oxygen doping-induced photogeneration loss in P3HT:PCBM solar cells, Solar Energy Materials and Solar Cells, 100 (2012) 185-191.

[25] F.C. Krebs, S.a. Gevorgyan, J. Alstrup, A roll-to-roll process to flexible polymer solar cells: model studies, manufacture and operational stability studies, Journal of Materials Chemistry, 19 (2009) 5442-5442. 
[26] M. Manceau, A. Rivaton, J.L. Gardette, S. Guillerez, N. Lemaître, The mechanism of photo- and thermooxidation of poly(3-hexylthiophene) (P3HT) reconsidered, Polymer Degradation and Stability, 94 (2009) 898-907.

[27] B. Conings, S. Bertho, K. Vandewal, A. Senes, J. D’Haen, J. Manca, R.a.J. Janssen, Modeling the temperature induced degradation kinetics of the short circuit current in organic bulk heterojunction solar cells, Applied Physics Letters, 96 (2010) 163301-163301.

[28] H.J. Kim, H.H. Lee, J.J. Kim, Real time investigation of the interface between a P3HT:PCBM layer and an al electrode during thermal annealing, Macromolecular Rapid Communications, 30 (2009) 1269-1273.

[29] G. Williams, Q. Wang, H. Aziz, The photo-stability of polymer solar cells: Contact photo-degradation and the benefits of interfacial layers, Advanced Functional Materials, 23 (2013) 2239-2247.

[30] J. Vandenbergh, B. Conings, S. Bertho, J. Kesters, D. Spoltore, S. Esiner, J. Zhao, G.V. Assche, M.M. Wienk, W. Maes, L. Lutsen, B.V. Mele, R.A.J. Janssen, J. Manca, D.J.M. Vanderzande, Thermal Stability of Poly[2-methoxy-5-(20-phenylethoxy)-1,4phenylenevinylene] (MPE-PPV):Fullerene Bulk Heterojunction Solar Cells, Macromolecules, (2011) 8470-8478.

[31] S. Bertho, I. Haeldermans, A. Swinnen, W. Moons, T. Martens, L. Lutsen, D. Vanderzande, J. Manca, A. Senes, A. Bonfiglio, Influence of thermal ageing on the stability of polymer bulk heterojunction solar cells, Solar Energy Materials and Solar Cells, 91 (2007) 385-389.

[32] S. Bertho, G. Janssen, T.J. Cleij, B. Conings, W. Moons, A. Gadisa, J. D’Haen, E. Goovaerts, L. Lutsen, J. Manca, D. Vanderzande, Effect of temperature on the morphological and photovoltaic stability of bulk heterojunction polymer:fullerene solar cells, Solar Energy Materials and Solar Cells, 92 (2008) 753-760.

[33] I.T. Sachs-Quintana, T. Heumüller, W.R. Mateker, D.E. Orozco, R. Cheacharoen, S. Sweetnam, C.J. Brabec, M.D. McGehee, Electron Barrier Formation at the OrganicBack Contact Interface is the First Step in Thermal Degradation of Polymer Solar Cells, Advanced Functional Materials, 24 (2014) 3978-3985.

[34] A. Guerrero, M. Pfannmöller, A. Kovalenko, T.S. Ripolles, H. Heidari, S. Bals, L.d. Kaufmann, J. Bisquert, G. Garcia-belmonte, Nanoscale mapping by electron energyloss spectroscopy reveals evolution of organic solar cell contact selectivity, Organic Electronics, 16 (2015) 227-233.

[35] I. Cardinaletti, J. Kesters, S. Bertho, B. Conings, F. Piersimoni, J. D’Haen, L. Lutsen, M. Nesladek, B. Van Mele, G. Van Assche, K. Vandewal, A. Salleo, D. Vanderzande, W. Maes, J.V. Manca, Toward bulk heterojunction polymer solar cells 
with thermally stable active layer morphology, Journal of Photonics for Energy, 4 (2014) 040997-040997.

[36] T. Wang, A.J. Pearson, A.D.F. Dunbar, P.a. Staniec, D.C. Watters, H. Yi, A.J. Ryan, R.a.L. Jones, A. Iraqi, D.G. Lidzey, Correlating Structure with Function in Thermally Annealed PCDTBT:PC70BM Photovoltaic Blends, Advanced Functional Materials, 22 (2012) 1399-1408.

[37] T.S. Ripolles, A. Guerrero, G. Garcia-Belmonte, Polymer defect states modulate open-circuit voltage in bulk-heterojunction solar cells, Applied Physics Letters, 103 (2013) 243306-243306.

[38] A. Guerrero, H. Heidari, T.S. Ripolles, A. Kovalenko, M. Pfannmöller, S. Bals, L.D. Kauffmann, J. Bisquert, G. Garcia-Belmonte, Shelf Life Degradation of Bulk Heterojunction Solar Cells : Intrinsic Evolution of Charge Transfer Complex, Advanced Energy Materials, (2014) DOI: 10.1002/aenm.201401997.

[39] Y. Zhao, G. Yuan, P. Roche, M. Leclerc, A calorimetric study of the phase transitions in poly(3-hexylthiophene), Polymer, 36 (1995) 2211-2214.

[40] T. Wang, A.J. Pearson, D.G. Lidzey, R.a.L. Jones, Evolution of Structure, Optoelectronic Properties, and Device Performance of Polythiophene:Fullerene Solar Cells During Thermal Annealing, Advanced Functional Materials, 21 (2011) 13831390.

[41] M.J. Richardson, N.G. Savill, Derivation of accurate glass transition temperatures by differential scanning calorimetry, Polymer, 16 (1975) 753-757.

[42] J.M. Torres, C. Wang, E.B. Coughlin, J.P. Bishop, R.A. Register, R.A. Riggleman, C.M. Sta, B.D. Vogt, Influence of Chain Stiffness on Thermal and Mechanical Properties of Polymer Thin Films, Macromolecules, 44 (2011) 9040-9045.

[43] T. Wang, A.J. Pearson, A.D.F. Dunbar, P.a. Staniec, D.C. Watters, D. Coles, H. Yi, A. Iraqi, D.G. Lidzey, R.a.L. Jones, Competition between substrate-mediated $\pi-\pi$ stacking and surface-mediated $\mathrm{T}(\mathrm{g})$ depression in ultrathin conjugated polymer films, The European physical journal. E, Soft matter, 35 (2012) 9807-9807.

[44] A. Shavit, R.A. Riggleman, Influence of Backbone Rigidity on Nanoscale Con fi nement E ff ects in Model Glass-Forming Polymers, Macromolecules, 46 (2013) 50445052 .

[45] D. Liu, R. Osuna Orozco, T. Wang, Deviations of the glass transition temperature in amorphous conjugated polymer thin films, Physical Review E, 88 (2013) 022601022601. 
[46] X. Yang, A. Alexeev, M.A.J. Michels, J. Loos, Effect of Spatial Confinement on the Morphology Evolution of Thin Poly ( $\mathrm{p}$-phenylenevinylene )/ Methanofullerene Composite Films, Macromolecules, 38 (2005) 4289-4295.

[47] M. Bolognesi, D. Gedefaw, D. Dang, P. Henriksson, W. Zhuang, M. Tessarolo, E. Wang, M. Muccini, M. Seri, M.R. Andersson, 2D $\pi$-conjugated benzo[1,2-b:4,5$\mathrm{b}^{\prime}$ ]dithiophene- and quinoxaline-based copolymers for photovoltaic applications, RSC Advances, 3 (2013) 24543-24543.

[48] A. Guerrero, L.F. Marchesi, P.P. Boix, S. Ruiz-Raga, T. Ripolles-Sanchis, G. Garcia-Belmonte, J. Bisquert, How the charge-neutrality level of interface states controls energy level alignment in cathode contacts of organic bulk-heterojunction solar cells, ACS nano, 6 (2012) 3453-3460.

[49] S.C. Price, a.C. Stuart, L.G. Yang, H.X. Zhou, W. You, Fluorine substituted conjugated polymer of medium bandwidth yield $7 \%$ efficiency in polymer-fullerine solar cells, Journal of the American Chemical Society, 133 (2011) 4625-4631.

[50] J. Kesters, S. Kudret, S. Bertho, N. Van Den Brande, M. Defour, B. Van Mele, H. Penxten, L. Lutsen, J. Manca, D. Vanderzande, W. Maes, Enhanced intrinsic stability of the bulk heterojunction active layer blend of polymer solar cells by varying the polymer side chain pattern, Organic Electronics: physics, materials, applications, 15 (2014) 549562.

[51] S. Bertho, B. Campo, F. Piersimoni, D. Spoltore, J. D'Haen, L. Lutsen, W. Maes, D. Vanderzande, J. Manca, Improved thermal stability of bulk heterojunctions based on side-chain functionalized poly(3-alkylthiophene) copolymers and PCBM, Solar Energy Materials and Solar Cells, 110 (2013) 69-76.

[52] J. Kesters, S. Kudret, S. Bertho, N. Van den Brande, M. Defour, B. Van Mele, H. Penxten, L. Lutsen, J. Manca, D. Vanderzande, W. Maes, Enhanced intrinsic stability of the bulk heterojunction active layer blend of polymer solar cells by varying the polymer side chain pattern, Organic Electronics, 15 (2014) 549-562.

[53] J. Zhao, A. Swinnen, G. Van Assche, J. Manca, D. Vanderzande, B. Van Mele, Phase Diagram of P3HT/PCBM Blends and Its Implication for the Stability of Morphology, Journal of Physical Chemistry B, 113 (2009) 1587-1591.

[54] N. Grossiord, J.M. Kroon, R. Andriessen, P.W.M. Blom, Degradation mechanisms in organic photovoltaic devices, Organic Electronics, 13 (2012) 432-456.

[55] D. Liu, T. Nagamori, M. Yabusaki, T. Yasuda, L. Han, K. Marumoto, Dramatic enhancement of fullerene anion formation in polymer solar cells by thermal annealing: Direct observation by electron spin resonance, Applied Physics Letters, 104 (2014) 243903-243903. 
[56] K. Vandewal, S. Himmelberger, A. Salleo, Structural Factors That Affect the Performance of Organic Bulk Heterojunction Solar Cells, Macromolecules, (2013).

[57] C. Lungenschmied, S. Bauer, R. Schwödiauer, S. Rodman, D. Fournier, G.

Dennler, C.J. Brabec, Real-time in-situ observation of morphological changes in organic bulk-heterojunction solar cells by means of capacitance measurements, Journal of Applied Physics, 109 (2011) 044503-044503.

[58] B. Bernardo, D. Cheyns, B. Verreet, R.D. Schaller, B.P. Rand, N.C. Giebink, Delocalization and dielectric screening of charge transfer states in organic photovoltaic cells, Nature communications, 5 (2014) 3245-3245.

[59] A.J. Pearson, T. Wang, R.A.L. Jones , D.G. Lidzey, Rationalizing Phase Transitions with Thermal Annealing Temperatures for P3HT:PCBM Organic Photovoltaic Devices, Macromolecules, 45 (2012) 1499-1508.

[60] M. Manceau, A. Rivaton, J.-L. Gardette, S. Guillerez, N. Lemaître, Light-induced degradation of the P3HT-based solar cells active layer, Solar Energy Materials and Solar Cells, 95 (2011) 1315-1325.

\section{Supporting Information}

\section{Predicting Thermal Stability of Organic Solar Cells Through an Easy and Fast Capacitance} Measurement

M. Tessarolo, ${ }^{a, b}$ A. Guerrero, ${ }^{b *}$, D. Gedefaw, ${ }^{c}$ M. Bolognesi, ${ }^{d}$ M. Prosa, ${ }^{a}$ X. Xu, ${ }^{c}$ M. Mansour, ${ }^{b}$ E. Wang, ${ }^{c}$ M. Seri, ${ }^{e^{*}}$ M. R. Andersson, ${ }^{c-f}$ M. Muccini, ${ }^{a}$ G. Garcia-Belmonte, ${ }^{b^{*}}$ 
${ }^{a}$ Consiglio Nazionale delle Ricerche (CNR), Istituto per lo Studio dei Materiali Nanostrutturati (ISMN), Via P. Gobetti, 101, 40129, Bologna, Italy.

${ }^{b}$ Photovoltaic and Optoelectronic Devices Group, Departament de Física, Universitat Jaume I, ES-12071 Castelló, Spain

${ }^{c}$ Department of Chemistry and Chemical Engineering, Polymer Technology, Chalmers University of Technology, Goteborg, SE-412 96, Sweden.

${ }^{d}$ Laboratory MIST E-R, Via P. Gobetti, 101, 40129, Bologna, Italy

${ }^{e}$ Consiglio Nazionale delle Ricerche (CNR), Istituto per la Sintesi Organica e la Fotoreattività (ISOF), Via P. Gobetti, 101, 40129, Bologna, Italy.

${ }^{f}$ Ian Wark Research Institute, University of South Australia, Mawson Lakes, South Australia 5095, Australia

Table S1: Molecular weight $\left(M_{n}\right)$ for each polymer.

\begin{tabular}{|l|c|c|c|c|c|}
\hline & $\mathrm{P}(1)$ & $\mathrm{P}(2)$ & $\mathrm{P}(3)^{*}$ & $\mathrm{P}(4)$ & $\mathrm{P}(5)$ \\
\hline $\begin{array}{l}\text { Molecular } \\
\text { Weight }\left(M_{\mathrm{n}}\right)\end{array}$ & $18 \mathrm{kDa}$ & $80-200 \mathrm{kDa}$ & $37 \mathrm{kDa}$ & $91 \mathrm{kDa}$ & $78 \mathrm{kDa}$ \\
\hline
\end{tabular}

* P3HT with $M_{n}=37 \mathrm{kDA}$ shows $T g=12^{\circ} \mathrm{C}^{1}$ 

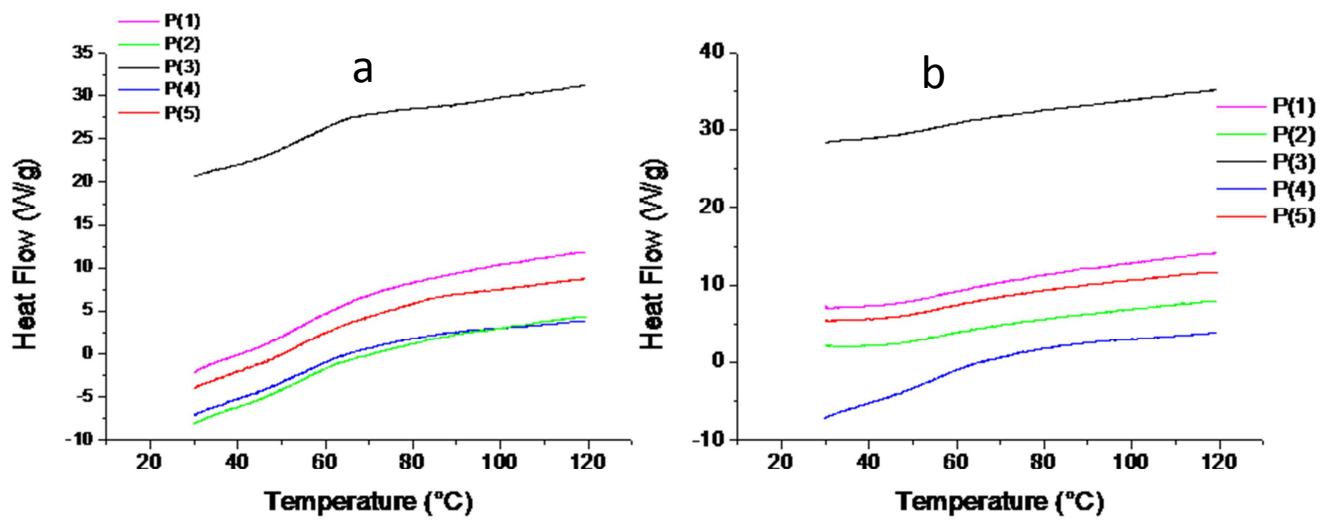

Figure S1: DSC of the pure polymers $\mathrm{P}(1)$ (pink), $\mathrm{P}(2)$ (green), $\mathrm{P}(3)$ (black), $\mathrm{P}(4)$ (blue) and $\mathrm{P}(5)$ (red) a) first heating cycle b) second heating cycle

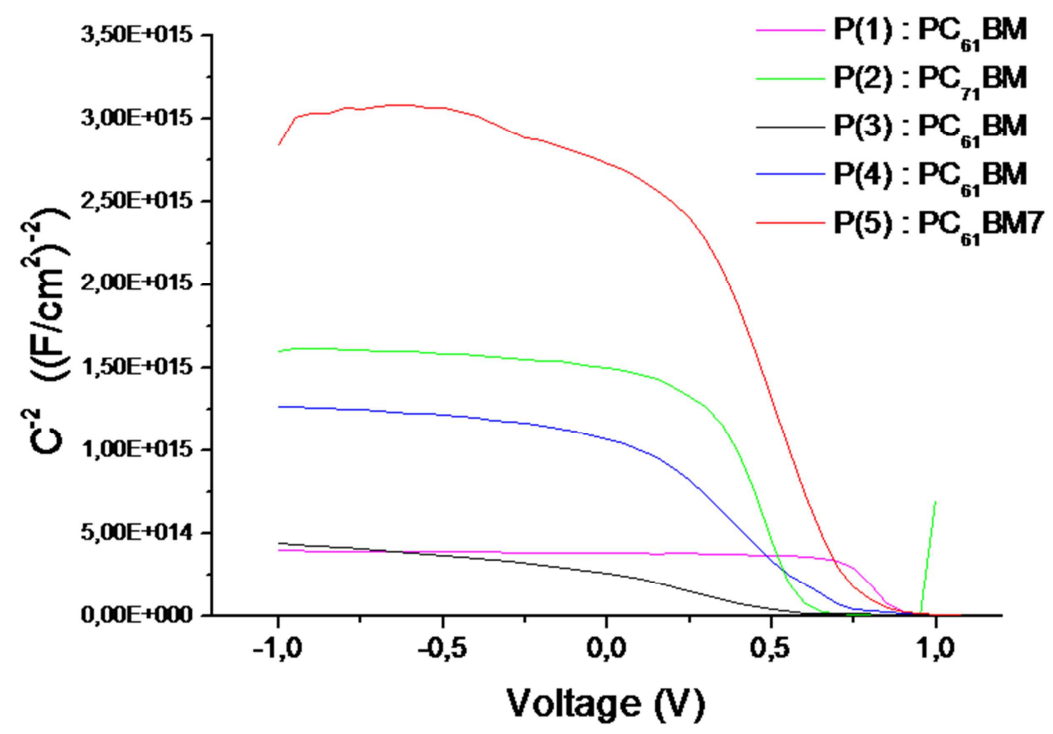

Figure S2: Mott Schottky curve of P(1) (pink), P(2) (green), P(3) (black), P(4) (blue) and P(5) (red) based solar cells

- Thermal degradation of $\mathrm{P}(1)$ based solar cells with different initial PCE 


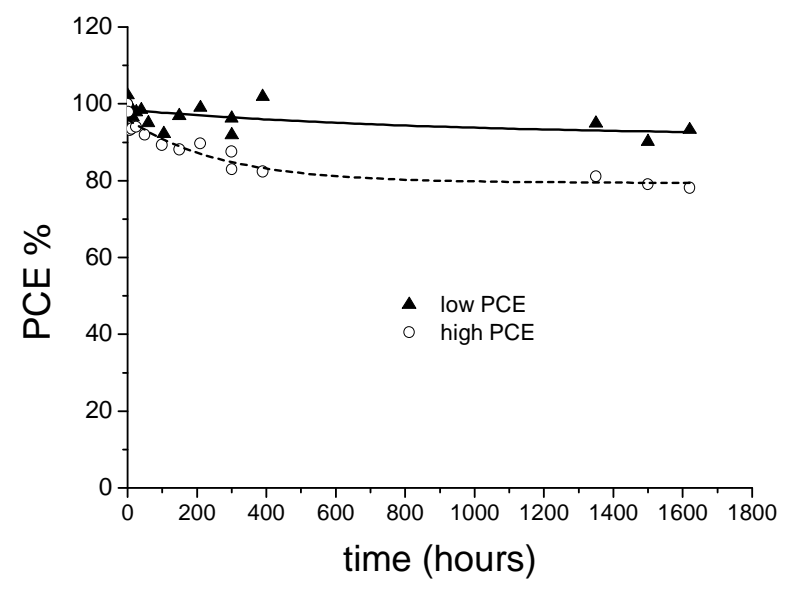

Figure S3: evolution with time of the normalized PCE during a thermal test at $85^{\circ} \mathrm{C}$ in the glovebox of two devices based of $\mathrm{P}(1)$ with different initial PCE.

Table S2: OPV Performance of the $\mathrm{P}(1)$ based BHJ solar cells with different before and after the thermal test. (a) Time constant $\tau$ and offset $\mathrm{PCE}_{\mathrm{f}}$ calculated from PCE decay during the thermal test at $85^{\circ} \mathrm{C}$ in glovebox, (b) value of $\mathrm{T}_{\mathrm{MAX}}$ obtained from the capacitance versus temperature measurement.

\begin{tabular}{ccccccccc}
$\begin{array}{c}\text { Donor } \\
\text { material }\end{array}$ & $\begin{array}{c}\text { Time } \\
(\mathbf{h})\end{array}$ & $\begin{array}{c}\boldsymbol{J}_{\mathbf{s c}} \\
\left(\mathbf{m A} / \mathbf{c m}^{2}\right)\end{array}$ & $\boldsymbol{V}_{\mathbf{o c}}(\mathbf{V})$ & $\mathbf{F F}$ & $\mathbf{P C E}$ & $\begin{array}{c}\boldsymbol{\tau}^{(\mathbf{a})} \\
(\mathbf{h})\end{array}$ & $\mathbf{P C E}_{f}^{(\mathbf{a})}$ & $\begin{array}{c}\boldsymbol{T}_{\boldsymbol{M A X}}{ }^{(\mathbf{b})} \\
\left({ }^{\circ} \mathbf{C}\right)\end{array}$ \\
\hline P(1) low PCE & 0 & 7,3 & 0,89 & $47 \%$ & $3,1 \%$ & 15 & $92 \%$ & 102 \\
\hline P(1) high & 0 & 7,5 & 0,85 & $46 \%$ & $2,9 \%$ & & & 87 \\
PCE & 20 & 8,1 & 0,89 & $57 \%$ & $4,1 \%$ & 4,5 & $79 \%$ & 87
\end{tabular}

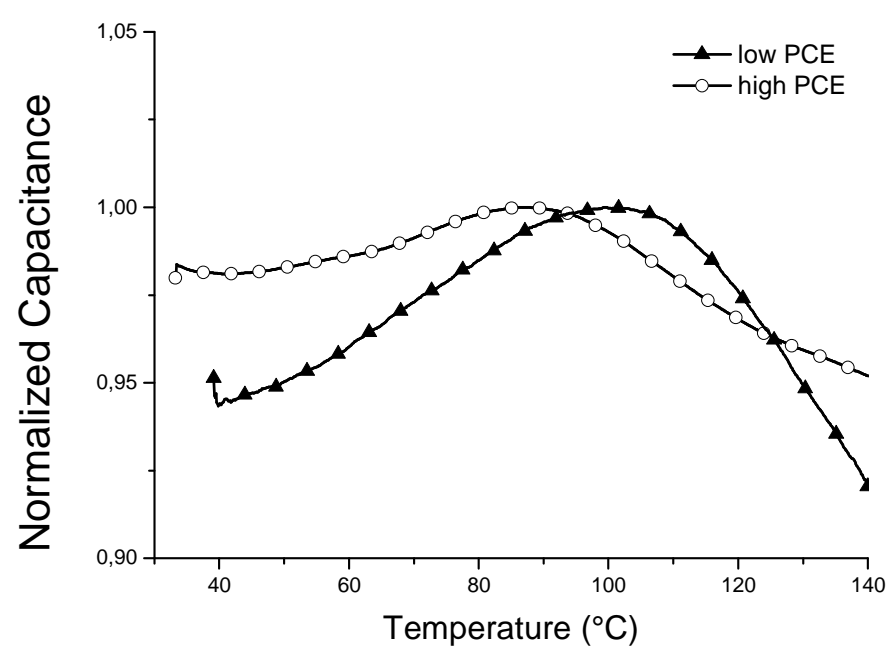


Figure S4: Normalized Capacitance of complete devices thermally treated with a heating ramp of $1{ }^{\circ} \mathrm{C} / \mathrm{min}$. The The maximum of the Capacitance-Temperature $\left(\mathrm{T}_{\mathrm{MAX}}\right)$ is indicated in the graph for each system.

- Estimation of the thermal expansion

We define: $\mathrm{V}=\mathrm{A} * \mathrm{t}$ and $\mathrm{C}=\varepsilon \varepsilon_{0} \mathrm{~A} / \mathrm{t}$

where $\mathrm{V}$ is the Volume of the BHJ, A the area $\left(6 \mathrm{~mm}^{2}\right)$, $\mathrm{t}$ the thickness of the $\mathrm{BHJ}, \mathrm{C}$ the capacitance, $\varepsilon$ the dielectric constant of the $\mathrm{BHJ}, \varepsilon_{0}$ the vacuum permittivity.

Proof that the capacitance value changes due to the thermal expansion, the expansion coefficient $\alpha$ would be:

$\alpha=\left(\mathrm{V}_{2}-\mathrm{V}_{1} / \mathrm{V}_{1}\right) *\left(1 /\left(\mathrm{T}_{2}-\mathrm{T}_{1}\right)\right)=\left(\mathrm{t}_{2}-\mathrm{t}_{1} / \mathrm{t}_{1}\right) *\left(1 /\left(\mathrm{T}_{2}-\mathrm{T}_{1}\right)\right)=\left(\mathrm{C}_{2}-\mathrm{C}_{1} / \mathrm{C}_{1}\right) *\left(1 /\left(\mathrm{T}_{2}-\right.\right.$

$\left.\mathrm{T}_{1}\right)$ )

Table S3: Measurements of the thickness and the capacitance values of $\mathrm{P}(1)$ based solar cell. Estimation of the expansion coefficient from those parameters.

\begin{tabular}{|c|c|c|c|}
\hline $\begin{array}{c}\text { Thickness before } \\
\text { C-T curve }\end{array}$ & $\begin{array}{c}\text { Thickness } \\
\text { after C-T curve }\end{array}$ & $\begin{array}{c}\text { Capacitance value } \\
@ \mathrm{~T}_{1}=30^{\circ} \mathrm{C}\end{array}$ & $\begin{array}{c}\text { Capacitance } \\
\text { value } \\
@ \mathrm{~T}_{2}=140^{\circ} \mathrm{C}\end{array}$ \\
\hline $\mathrm{t}_{1}=163 \mathrm{~nm}$ & $\mathrm{t}_{2}=193 \mathrm{~nm}$ & $\mathrm{C}_{1}=3,25 \mathrm{nF}$ & $\mathrm{C}_{2}=3,15 \mathrm{nF}$ \\
\hline $\begin{array}{c}\text { Estimation of Expansion coefficient from } \\
\text { the thickness }\end{array}$ & $\begin{array}{c}\text { Estimation of Expansion coefficient } \\
\text { from the capacitance }\end{array}$ \\
\hline \multicolumn{2}{|r|}{$1,8 \times 10^{-3} \mathrm{~K}^{-1}$} & \multicolumn{2}{|c|}{$2,3 \times 10^{-4} \mathrm{~K}^{-1}$} \\
\hline
\end{tabular}

Those different results suggest that the changes in the BHJ during the C-T measurement, cannot be described as a simple thermal expansion.

- Degradation of $\mathrm{P}(1)$ based solar cells at $120^{\circ} \mathrm{C}$ in glovebox. 


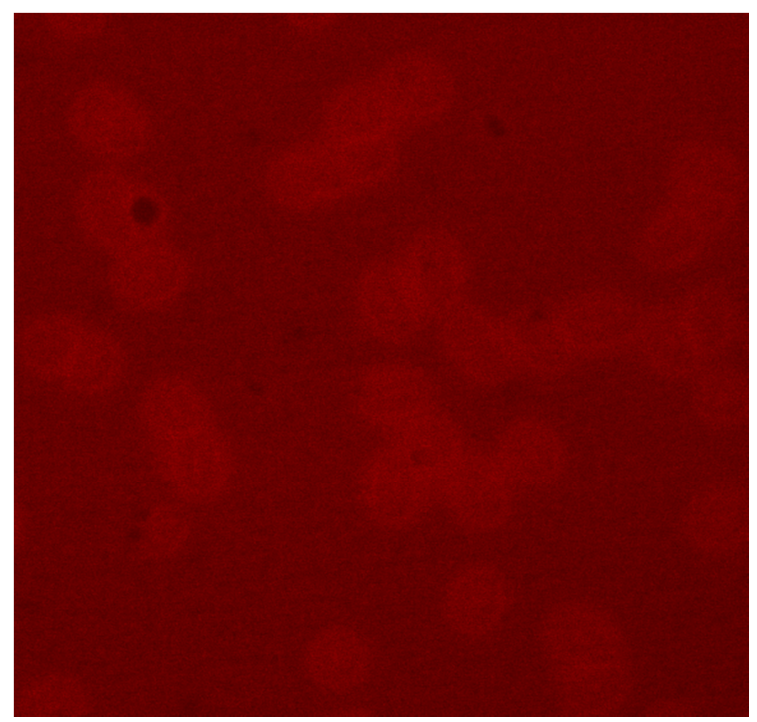

Figure S5: Confocal Images of $\mathrm{P}(1)$ based solar cell after $5 \mathrm{~h}$ at $120^{\circ} \mathrm{C}$ in glovebox.

Table S4: OPV parameters of $\mathrm{P}(1)$ based solar cell during the thermal test at $120^{\circ} \mathrm{C}$ in glovebox.

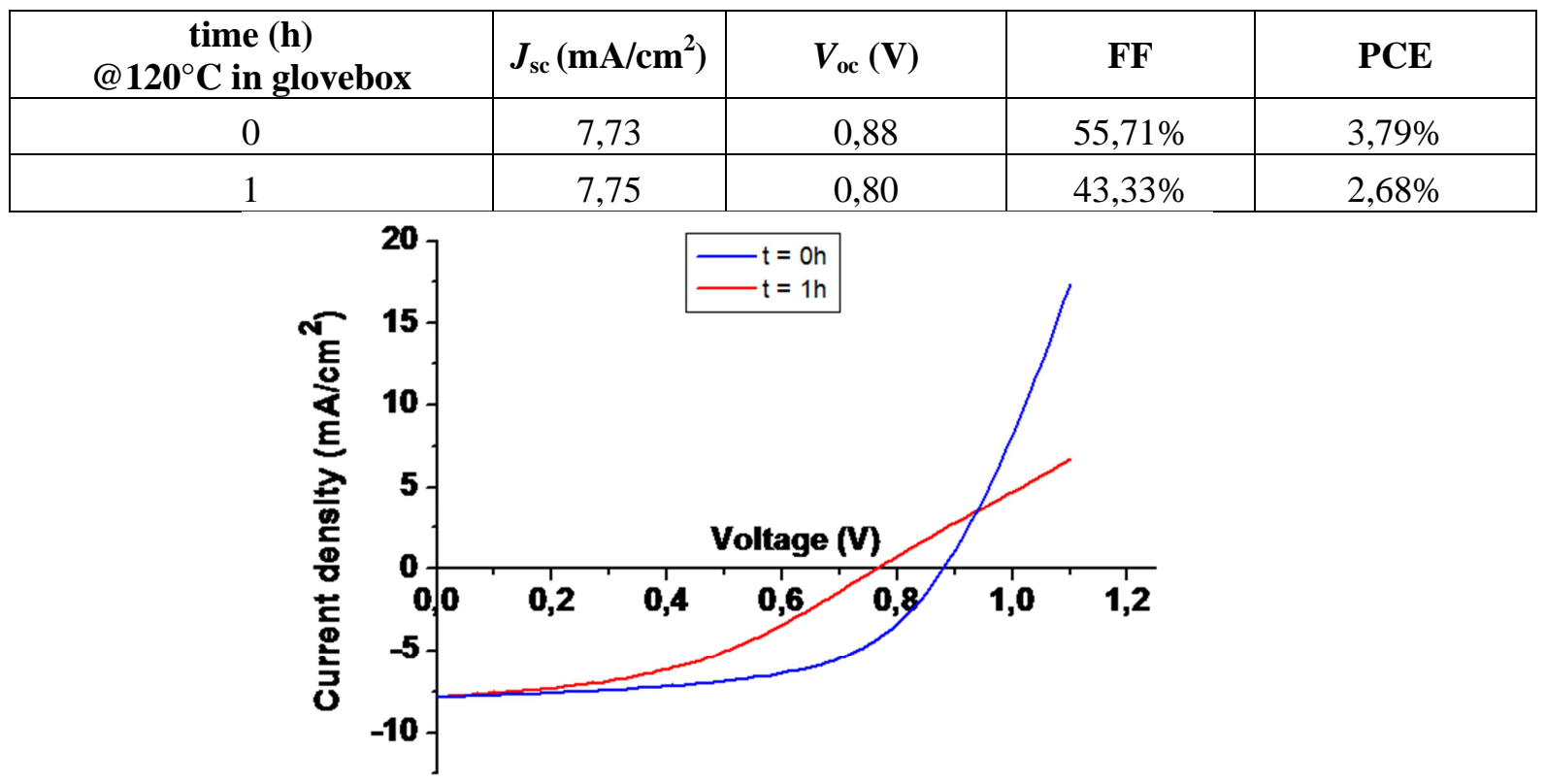

Figure S6: $J-V$ curve of $\mathrm{P}(1)$ based solar cells during a thermal test at $120^{\circ} \mathrm{C}$ in glovebox. 
- Synthesis of polymer P(4)-PTT-MIM

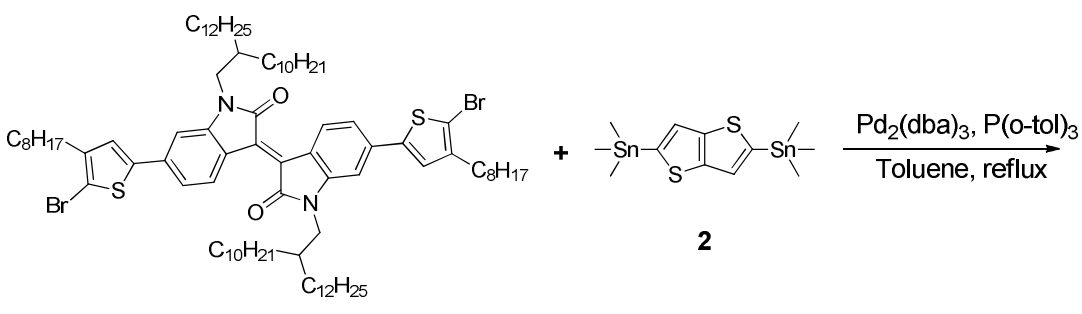

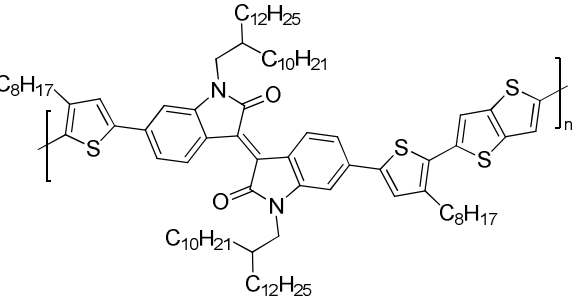

P(4)-PTT-MIM

In a $50 \mathrm{~mL}$ dry flask, monomer $1(370.5 \mathrm{mg}, 0.25 \mathrm{mmol}), 2,5-$

bis(trimethylstannyl)thieno[3,2-b]thiophene (monomer 2) (116.5 mg, $0.25 \mathrm{mmol}$ ),

tris(dibenzylideneacetone)dipalladium $(0)\left(\mathrm{Pd}_{2}(\mathrm{dba})_{3}\right)(4.6 \mathrm{mg})$ and tri(o-tolyl)phosphine $(\mathrm{P}(o-$ $\left.\mathrm{Tol})_{3}\right)(6.1 \mathrm{mg})$ were dissolved in anhydrous toluene $(12 \mathrm{~mL})$ under a nitrogen atmosphere. The reaction mixture was refluxed with vigorous stirring for $24 \mathrm{~h}$. After cooling to room temperature, the polymer was precipitated by pouring the solution into acetone and was collected by filtration through a $0.45 \mu \mathrm{m}$ Teflon filter. Then the polymer was washed in a Soxhlet extractor with acetone, diethyl ether and chloroform. The chloroform fraction was purified by passing it though a short silica gel column and then precipitated from diethyl ether. Finally, the polymer was obtained by filtration through $0.45 \mu \mathrm{m}$ Teflon filter and dried under vacuum at $40^{\circ} \mathrm{C}$ overnight $(292 \mathrm{mg}, 60 \%)$. Molecular Weight: $M_{\mathrm{n}}=91.0 \mathrm{kDa} ; M_{\mathrm{w}} / M_{\mathrm{n}}=2.8$.

\section{References}

1 J. Kesters, S. Kudret, S. Bertho, N. Van Den Brande, M. Defour, B. Van Mele, H. Penxten, L. Lutsen, J. Manca, D. Vanderzande and W. Maes, Org. Electron. physics, Mater. Appl., 2014, 15, 549-562. 